\title{
Variation of molecular stacking with different length of alkyl chain: synthesis, structure determination, and mesogenic study of $\mathrm{N}, \mathrm{N}$-disubstituted aminophenylazo-(4)-p-alkylbenzenes
}

\author{
LONG-LI LAI*†, LING-YUNG WANG $\dagger$, HUI-FANG TZENG $\dagger$, JIAN-WEN LIN $\dagger$, SHENG-MING HUANG \\ KUANG-LIEH LU‡, YI-HUNG LIU§ and YU WANG§ \\ $\dagger$ Department of Applied Chemistry, National Chi Nan University, Puli, Taiwan 545, ROC \\ ¥Institute of Chemistry, Academia Sinica, Taipei, Taiwan 115, ROC \\ §Instrumentation Center and Department of Chemistry, National Taiwan University, Taipei, Taiwan 106, ROC
}

(Received 26 July 2004; in final form 17 October 2004; accepted 10 November 2004)

\begin{abstract}
To help understand the influence of polarity and length of the terminal alkyl chain of a molecule on the molecular stacking of a liquid crystal and on its mesogenic behaviour, four new aminophenylazo-(4)-p-alkylbenzenes were prepared and one of them was further studied by single crystal structure determination. The molecular stacking based on this crystallographic data was established, and compared with that of two previously reported homologues. The mesogenic behaviour of this series of compounds was also investigated.
\end{abstract}

\section{Introduction}

Supramolecular aggregation by molecular self-assembly is an important issue in the field of structural chemistry [1]. In addition to electrostatic interaction, non-covalent forces also play a significant role in determining the structural stacking and properties of molecular assemblies [2]. The interaction between functional molecules is found to be critical for molecular packing in crystallization [3], and the stability and phase behaviour of mesogenic molecules have been reported to arise therefrom [4]. We previously reported the preparation of liquid crystal azo dyes $\mathbf{1 a}$ and $\mathbf{2 c}$ in a primary communication [5a]. Although the $\mathrm{N}-\mathrm{CO}$ dipole and benzene moiety significantly influence molecular packing in the solid state, the lengths of terminal alkyl chain and weak intermolecular H-bond interaction, also contribute to the solid stacking, and consequently may affect the mesogenic behaviour. In particular, we found that a dramatic mesogenic variation (from smectic B to nematic phase) arose simply by changing the length of alkyl chain (from $\mathrm{C}_{9} \mathrm{H}_{19}$ to $\mathrm{C}_{7} \mathrm{H}_{15}$ ) in azo dyes $\mathbf{3 b}$ and $\mathbf{3 a}$ [5b]. A more complete study of this series of azo dyes was thus encouraged, and is now reported.

\section{Experimental}

The chemicals used were commercially available from ACROS. Mesogenic behaviour and phase transitions were

*Corresponding author. Email: lilai@ncnu.edu.tw characterized by polarizing optical microscopy (POM) and differential scanning calorimetry (Perkin-Elmer DSC 6). Powder X-ray diffraction (XRD) patterns were obtained from a Siemens D-5000 X-ray diffractometer equipped with a TTK 450 temperature controller and $\mathrm{Cu}$ radiation with wavelength length $\lambda=1.5406 \AA$. The molecular stackings of compounds $\mathbf{1 a}, \mathbf{2 a}$ and $\mathbf{2 c}$ were obtained from crystallographic data using the CAChe program.

\subsection{Synthesis of compounds 1 and 2}

The phenylpiperazine derivative $4\left(R^{\prime}=\mathrm{C}_{5} \mathrm{H}_{11}\right.$ or $\mathrm{C}_{9} \mathrm{H}_{19}$ ) was prepared according to our previous procedure $[6 a]$ in almost quantitative yield. The diazonium salt $5\left(R=\mathrm{C}_{2} \mathrm{H}_{5}, \mathrm{C}_{4} \mathrm{H}_{9}\right.$ or $\left.\mathrm{C}_{6} \mathrm{H}_{13}\right)$ was prepared by a literature process [6 b] in $50-70 \%$ yield. Compound 5 (3 mmol) was dissolved in acetone $(5 \mathrm{ml})$, and compound $4(2 \mathrm{mmol})$ in $\mathrm{CH}_{2} \mathrm{Cl}_{2}(5 \mathrm{ml})$ was added. The resulting solution was allowed to stand at room temperature for $24 \mathrm{~h}$. The solvent was removed at reduced pressure and the residue was dissolved in dichloromethane $(5 \mathrm{ml})$; this solution was then purified by chromatography and the product (compounds $\mathbf{1}$ or 2 ) recrystallized from $\mathrm{CH}_{2} \mathrm{Cl}_{2}$ /hexane (1/3) for the further physical study. Compounds $\mathbf{1 a}-\mathbf{1 c}$ and $\mathbf{2 a - 2 c}$ were all prepared in a similar manner [5a]. The new compounds $\mathbf{1 b}, \mathbf{1 c}, \mathbf{2 a}$ and 2b were characterized by ${ }^{1} \mathrm{H}$ NMR (Varian $300 \mathrm{MHz}$ FTNMR spectrometer) at room temperature also by 
using $\mathrm{CDCl}_{3}(7.24 \mathrm{ppm})$ as internal standard ( $\mathrm{s}=$ singlet, $\mathrm{d}=$ doublet, $\mathrm{t}=$ triplet, $\mathrm{b}=$ broad); high resolution mass spectrometry (VG70-250; EI, 70 ev) and elemental analysis (Heraeus).

Compound 1b. Yield 22.8\% (0.19g). ${ }^{1} \mathrm{H}$ NMR: $\delta$ $\left(\mathrm{CDCl}_{3}\right)$ 0.87-0.95 (mix. of 2t, $\left.6 \mathrm{H}, 2 \times \mathrm{CH}_{3}\right), 1.31-1.73$ $\left(\mathrm{m}, 10 \mathrm{H}, 5 \times \mathrm{CH}_{2}\right), 2.38\left(\mathrm{t}, 2 \mathrm{H}, J=7.8 \mathrm{~Hz}, \mathrm{CH}_{2}\right), 2.72(\mathrm{t}$, $\left.2 \mathrm{H}, J=7.8 \mathrm{~Hz}, \mathrm{CH}_{2}\right), 3.33$ (s, b, $\left.4 \mathrm{H}, 2 \times \mathrm{CH}_{2}\right), 3.64$ (s, b, $\left.2 \mathrm{H}, \mathrm{CH}_{2}\right), 3.79\left(\mathrm{~s}, \mathrm{~b}, 2 \mathrm{H}, \mathrm{CH}_{2}\right), 6.99(\mathrm{~d}, 2 \mathrm{H}, J=8.7 \mathrm{~Hz}$, $2 \times \mathrm{Ar}-\mathrm{H}), 7.27(\mathrm{~d}, 2 \mathrm{H}, J=8.1 \mathrm{~Hz}, 2 \times \mathrm{Ar}-\mathrm{H}), 7.78(\mathrm{~d}$, $2 \mathrm{H}, J=8.7 \mathrm{~Hz}, 2 \times \mathrm{Ar}-\mathrm{H}), 7.87(\mathrm{~d}, 2 \mathrm{H}, J=8.1 \mathrm{~Hz}$, $2 \times \mathrm{Ar}-\mathrm{H})$. HRMS for $\mathrm{C}_{26} \mathrm{H}_{36} \mathrm{~N}_{4} \mathrm{O}$ 420.2889; found 420.2888. Analytical data for $\mathrm{C}_{26} \mathrm{H}_{36} \mathrm{~N}_{4} \mathrm{O}$ : calcd $\mathrm{C}$ 74.23, H 8.63, N 13.33; found $\mathrm{C} 74.24, \mathrm{H} 8.68, \mathrm{~N}$ $13.32 \%$.

Compound 1c. Yield 12.9\% (0.12g). ${ }^{1} \mathrm{H}$ NMR: $\delta$ $\left(\mathrm{CDCl}_{3}\right)$ 0.86-0.96 (mix. of $\left.2 \mathrm{t}, 6 \mathrm{H}, 2 \times \mathrm{CH}_{3}\right), 1.31-$ $1.75\left(\mathrm{~m}, 14 \mathrm{H}, 7 \times \mathrm{CH}_{2}\right), 2.38\left(\mathrm{t}, 2 \mathrm{H}, J=7.8 \mathrm{~Hz}, \mathrm{CH}_{2}\right)$, $2.70\left(\mathrm{t}, 2 \mathrm{H}, J=7.8 \mathrm{~Hz}, \mathrm{CH}_{2}\right), 3.20\left(\mathrm{~s}, \mathrm{~b}, 2 \mathrm{H}, \mathrm{CH}_{2}\right), 3.38$ (s,b, 2H, $\left.\mathrm{CH}_{2}\right), 3.68$ (s, b, 2H, $\left.\mathrm{CH}_{2}\right), 3.83\left(\mathrm{~s}, \mathrm{~b}, 2 \mathrm{H}, \mathrm{CH}_{2}\right)$, $7.00(\mathrm{~d}, \quad 2 \mathrm{H}, \quad J=8.7 \mathrm{~Hz}, 2 \times \mathrm{Ar}-\mathrm{H}), 7.31(\mathrm{~d}, 2 \mathrm{H}$, $J=8.1 \mathrm{~Hz}, 2 \times \mathrm{Ar}-\mathrm{H}), 7.81(\mathrm{~d}, 2 \mathrm{H}, J=8.7 \mathrm{~Hz}, 2 \times \mathrm{Ar}-$ $\mathrm{H}), 7.90(\mathrm{~d}, 2 \mathrm{H}, J=8.1 \mathrm{~Hz}, 2 \times \mathrm{Ar}-\mathrm{H})$. HRMS for $\mathrm{C}_{28} \mathrm{H}_{40} \mathrm{~N}_{4} \mathrm{O}$ 448.3202; found 448.3200. Analytical data for $\mathrm{C}_{28} \mathrm{H}_{40} \mathrm{~N}_{4} \mathrm{O}$ : calcd $\mathrm{C} 74.95, \mathrm{H} 8.99, \mathrm{~N} 12.49$; found C 74.96, H 9.10, N 12.48\%.

Compound 2a. Yield 32.9\% $(0.30 \mathrm{~g}) .{ }^{1} \mathrm{H}$ NMR: $\delta$ $\left(\mathrm{CDCl}_{3}\right) 0.86\left(\mathrm{t}, 3 \mathrm{H}, J=6.6 \mathrm{~Hz}, \mathrm{CH}_{3}\right), 1.15-1.73(\mathrm{~m}$, $\left.17 \mathrm{H}, 7 \times \mathrm{CH}_{2}+\mathrm{CH}_{3}\right), 2.35\left(\mathrm{t}, 2 \mathrm{H}, J=7.8 \mathrm{~Hz}, \mathrm{CH}_{2}\right), 2.70$ (quart, $\left.2 \mathrm{H}, \mathrm{CH}_{2}\right), 3.36\left(\mathrm{~s}, \mathrm{~b}, 4 \mathrm{H}, 2 \times \mathrm{CH}_{2}\right), 3.70(\mathrm{~s}, \mathrm{~b}, 2 \mathrm{H}$, $\left.\mathrm{CH}_{2}\right), 3.84\left(\mathrm{~s}, \mathrm{~b}, 2 \mathrm{H}, \mathrm{CH}_{2}\right), 7.08(\mathrm{~d}, 2 \mathrm{H}, J=8.7 \mathrm{~Hz}$, $2 \times \mathrm{Ar}-\mathrm{H}), 7.29(\mathrm{~d}, 2 \mathrm{H}, J=8.1 \mathrm{~Hz}, 2 \times \mathrm{Ar}-\mathrm{H}), 7.81(\mathrm{~d}$, $2 \mathrm{H}, J=8.7 \mathrm{~Hz}, 2 \times \mathrm{Ar}-\mathrm{H}), 7.92(\mathrm{~d}, 2 \mathrm{H}, J=8.1 \mathrm{~Hz}$, $2 \times \mathrm{Ar}-\mathrm{H})$. HRMS for $\mathrm{C}_{28} \mathrm{H}_{40} \mathrm{~N}_{4} \mathrm{O} 448.3199$; found 448.3202. Analytical data for $\mathrm{C}_{28} \mathrm{H}_{40} \mathrm{~N}_{4} \mathrm{O}$ : calcd $\mathrm{C}$ $74.95, \mathrm{H}$ 8.99, N 12.49; found $\mathrm{C} 74.87, \mathrm{H} 9.00, \mathrm{~N}$ $12.56 \%$.

Compound 2b. Yield 22.8\% (0.19g). ${ }^{1} \mathrm{H}$ NMR: $\delta$ $\left(\mathrm{CDCl}_{3}\right)$ 0.83-0.94 (mix. of 2t, 6H, $2 \times \mathrm{CH}_{3}$ ), 1.25-1.67 $\left(\mathrm{m}, 18 \mathrm{H}, 9 \times \mathrm{CH}_{2}\right), 2.35\left(\mathrm{t}, 2 \mathrm{H}, J=7.8 \mathrm{~Hz}, \mathrm{CH}_{2}\right), 2.66(\mathrm{t}$, $\left.2 \mathrm{H}, J=7.8 \mathrm{~Hz}, \mathrm{CH}_{2}\right), 3.34\left(\mathrm{~s}, \mathrm{~b}, 4 \mathrm{H}, 2 \times \mathrm{CH}_{2}\right), 3.68(\mathrm{~s}, \mathrm{~b}$, $\left.2 \mathrm{H}, \mathrm{CH}_{2}\right), 3.83\left(\mathrm{~s}, \mathrm{~b}, 2 \mathrm{H}, \mathrm{CH}_{2}\right), 7.02(\mathrm{~d}, 2 \mathrm{H}, J=8.7 \mathrm{~Hz}$, $2 \times \mathrm{Ar}-\mathrm{H}), 7.29(\mathrm{~d}, 2 \mathrm{H}, J=8.1 \mathrm{~Hz}, 2 \times \mathrm{Ar}-\mathrm{H}), 7.78(\mathrm{~d}$, $2 \mathrm{H}, J=8.7 \mathrm{~Hz}, 2 \times \mathrm{Ar}-\mathrm{H}), 7.88(\mathrm{~d}, 2 \mathrm{H}, J=8.1 \mathrm{~Hz}$, $2 \times \mathrm{Ar}-\mathrm{H})$. HRMS for $\mathrm{C}_{30} \mathrm{H}_{44} \mathrm{~N}_{4} \mathrm{O}$ 476.3516; found 476.3515. Analytical data for $\mathrm{C}_{30} \mathrm{H}_{44} \mathrm{~N}_{4} \mathrm{O}$ : calcd $\mathrm{C}$ 75.57, $\mathrm{H}$ 9.31, N 11.76; found $\mathrm{C} 75.56, \mathrm{H}$ 9.31, N $11.73 \%$.

\subsection{X-ray crystallography}

Crystals of compound 2a were grown from dichloromethane/hexane (1/1) at room temperature. A single orange crystal of suitable quality was mounted on a glass fibre and used for the measurement of precise cell constants and collection of intensity data. Diffraction measurements were made on a Nonius Kappa CCD diffractometer with graphite-monochromated Mo-K $\alpha$ radiation $(\lambda=0.71073 \AA)$, operating at $295(2) \mathrm{K}$ over the $\theta$ range $1.38^{\circ}-27.50^{\circ}$. No significant decay was observed during the data collection. Reflections (5472) were observed with $I \geq 2 \sigma(I)$ among the 11619 unique reflections, and 5422 reflections were used in the refinement. Data were processed on a PC using the SHELXTL software package [7]. The structure of 2a was solved using the direct method and refined by fullmatrix least squares on the $F^{2}$ value. All non-hydrogen atoms were refined anisotropically. The positions of hydrogen atoms were identified by calculation, and their contributions to structural factors were included. The final indices were $R 1=0.0615, w R 2=0.1304$ with goodness-of-fit on $F^{2}=0.992$.

Other data are as follows: formula $\mathrm{C}_{28} \mathrm{H}_{40} \mathrm{~N}_{4} \mathrm{O}$; formula weight 448.32 ; crystal size $0.30 \times 0.20 \times$ $0.05 \mathrm{~mm}^{3}$; unit cell $a=5.7360(4), \quad b=7.6130(6)$, $c=59.235(5), \alpha=\beta=\gamma=90^{\circ}$; crystal system orthorhombic; space group $P 2{ }_{1} 2_{1} 2_{1}$; volume $2586.7(3) \AA^{3}$; cell units (Z) 4; density(calcd.) $1.152 \mathrm{~g} \mathrm{~cm}^{-3}$; linear absorption coefficient $0.084 \mathrm{~cm}^{-1}$. Crystallographic data for the compound 2a have been deposited with Cambridge Crystallographic Data Center as supplementary publication No. CCDC 240605. Copies of the data can be obtained free of charge from the Director, CCDC, 12 Union Road, Cambridge CB2 1EZ, UK (fax: +44-1223-336033, e-mail: deposit@ccdc.cam.ac.uk).

\section{Results and discussion}

\subsection{Synthesis and mesogenic study}

Compounds 1a-2c were prepared in a similar manner according to the scheme $[5 a]$. Compounds $4 \mathbf{a}, \mathbf{b}$ were obtained by reaction of the $N$-phenylpiperazine with corresponding alkanoyl chlorides in dichloromethane in almost quantitative yield. The diazonium salt $\mathbf{5}$ was prepared according to the literature method $[6 b]$, and compounds 1a-2c were subsequently obtained as expected. The new compounds $\mathbf{1 b}, \mathbf{1 c}, \mathbf{2 a}$ and $\mathbf{2 b}$ were characterized by ${ }^{1} \mathrm{H}$ NMR, high resolution mass spectrometry and elemental analysis.

The phase transition temperatures and corresponding enthalpies for azo dyes 1a-2c, characterized by DSC (2nd scans at heating/cooling rates of $10^{\circ} \mathrm{Cmin}^{-1}$, $50-220^{\circ} \mathrm{C}$ ) and POM, are shown in the table. Azo dyes 1a-2c show a SmA phase characterized by typical focalconic textures and low viscosity. The SmA range for these dyes is about $45^{\circ}$ on heating or cooling. In general, 
<smiles>[R]C(=O)N1CCN(c2ccc(N=Nc3ccc([R])cc3)cc2)CC1</smiles>

1a: $\mathrm{R}^{\prime}=\mathrm{C}_{5} \mathrm{H}_{11}, \mathrm{R}=\mathrm{C}_{2} \mathrm{H}_{5}$

2c: $\mathrm{R}^{\prime}=\mathrm{C}_{9} \mathrm{H}_{21}, \mathrm{R}=\mathrm{C}_{6} \mathrm{H}_{13}$<smiles>[R]C(=O)Oc1ccc(N=Nc2ccc(C(=O)OCC)cc2)cc1</smiles>

3a $\mathrm{R}^{\prime \prime}=\mathrm{C}_{7} \mathrm{H}_{15}$

3b $\mathrm{R}^{\prime \prime}=\mathrm{C}_{9} \mathrm{H}_{21}$
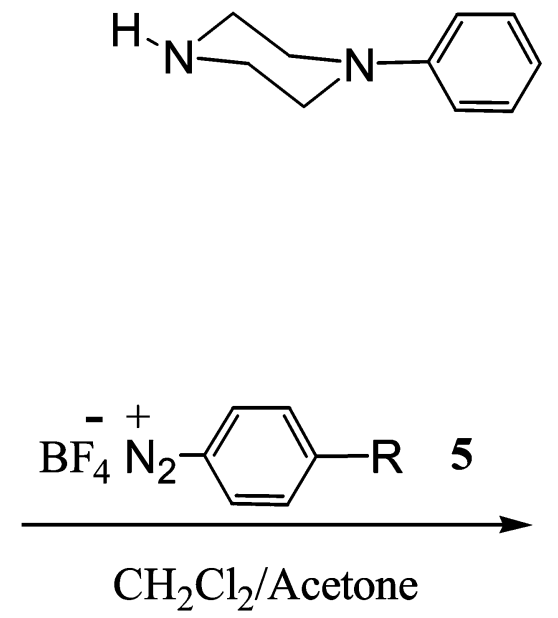

$\mathrm{CH}_{2} \mathrm{Cl}_{2} /$ Acetone

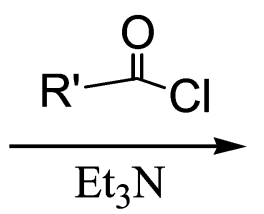<smiles>[R]C(=O)N1CCN(c2ccccc2)CC1</smiles>

4a $\mathrm{R}^{\prime}=\mathrm{C}_{5} \mathrm{H}_{11}$

4b $\mathrm{R}^{\prime}=\mathrm{C}_{9} \mathrm{H}_{21}$

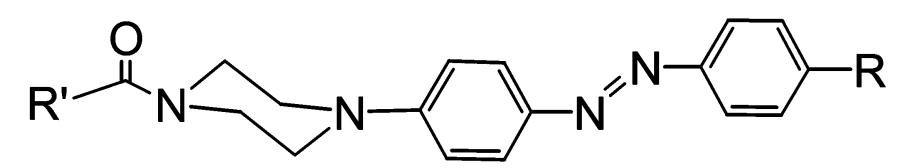

$$
\begin{aligned}
& \text { 1a: } \mathrm{R}^{\prime}=\mathrm{C}_{5} \mathrm{H}_{11}, \mathrm{R}=\mathrm{C}_{2} \mathrm{H}_{5} ; \mathbf{1 b}: \mathrm{R}^{\prime}=\mathrm{C}_{5} \mathrm{H}_{11}, \mathrm{R}=\mathrm{C}_{4} \mathrm{H}_{9} \\
& \text { 1c: } \mathrm{R}^{\prime}=\mathrm{C}_{5} \mathrm{H}_{11}, \mathrm{R}=\mathrm{C}_{6} \mathrm{H}_{13} ; \mathbf{2 a :} \mathrm{R}^{\prime}=\mathrm{C}_{9} \mathrm{H}_{21}, \mathrm{R}=\mathrm{C}_{2} \mathrm{H}_{5} \\
& \text { 2b: } \mathrm{R}^{\prime}=\mathrm{C}_{9} \mathrm{H}_{21}, \mathrm{R}=\mathrm{C}_{4} \mathrm{H}_{9} ; \text { 2c: } \mathrm{R}^{\prime}=\mathrm{C}_{9} \mathrm{H}_{21}, \mathrm{R}=\mathrm{C}_{6} \mathrm{H}_{13}
\end{aligned}
$$

Scheme.

the enthalpy difference between the $\operatorname{SmA}$ and isotropic phases for azo dyes 1a-c are slightly lower than the corresponding values for $\mathbf{2 a - c}$; this may result from different molecular stackings, to be discussed later.

\subsection{Crystallographic and physical study}

Compound 2a was studied by single crystal analysis; its stacking is shown in figure 1. Molecules of 2a are directed regularly head-to-head and tail-to-tail in the same layers (for example, molecules a1-a3 in layer A). However, molecules in adjacent layers are arranged head-to-tail (for example, molecules a1-a3 in layer A and molecules b1-b2 in layer B). In the same layer, the molecules lie parallel to adjacent molecules and the distances between two corresponding atoms in the same layer (for example, $\mathrm{Ca}-\mathrm{Cb}$ and $\mathrm{Na}-\mathrm{Nb}$ ) are all about $5.73 \AA$. Molecules of $\mathbf{2 a}$ in different layers are not parallel to each other, and the angle between the planes containing azobenzene moieties of the molecules in layers $\mathrm{A}$ and $\mathrm{B}$ is estimated to be about $80^{\circ}$ on the basis of the crystallographic data. Molecules of 1a are regularly arranged head-to-head with adjacent molecules in the $\mathrm{X}, \mathrm{Y}$ or $\mathrm{Z}$ columns (see figure 2) [5a]. However, molecules in different columns are packed in opposite directions; the molecules are found to be parallel to neighbouring molecules in the same layer (for example layer $\mathrm{A}$ in column $\mathrm{Z}$ ) and the distances between two corresponding atoms in the same layers (for example, $\mathrm{Na}-\mathrm{Nb}$ and $\mathrm{Ca}-\mathrm{Cb}$ ) are all about 7.6 . The planes containing azobenzene moieties of the molecules in layer A are approximately parallel to the 
Table. Phase transition temperature $\left({ }^{\circ} \mathrm{C}\right)$ and corresponding enthalpy changes $\left(\mathrm{kJ} \mathrm{mol}^{-1}\right)$, in parenthess, of compounds $\mathbf{1 a}-\mathbf{2} \mathbf{c}$. $\mathrm{Cr}=$ crystalline; $\mathrm{SmX}, \mathrm{SmX} 1=$ unidentified smectic phase; $\mathrm{SmA}=$ smectic A phase; $\mathrm{I}=$ isotropic liquid.<smiles>[R]C(=O)N1CCN(c2ccc(/N=N/c3ccc([R])cc3)cc2)CC1</smiles>

\begin{tabular}{|c|c|c|c|c|c|c|c|c|}
\hline \multirow[t]{2}{*}{$1 \mathrm{a}$} & \multirow{2}{*}{$\begin{array}{l}R=\mathrm{C}_{2} \mathrm{H}_{5} \\
R^{\prime}=\mathrm{C}_{5} \mathrm{H}_{11}\end{array}$} & \multirow{2}{*}{ SmX1 } & $125.7(104.3)$ & \multirow{2}{*}{$\operatorname{SmX}$} & $141.1(11.5)$ & \multirow{2}{*}{$\mathrm{SmA}$} & $187.4(29.6)$ & \multirow{2}{*}{ I } \\
\hline & & & $62.9(67.6)$ & & $137.6(9.2)$ & & $180.0(32.7)$ & \\
\hline \multirow[t]{2}{*}{$1 \mathrm{~b}$} & $R=\mathrm{C}_{4} \mathrm{H}_{9}$ & \multirow{2}{*}{$\mathrm{Cr}$} & $110.3(87.4)$ & \multirow{2}{*}{$\operatorname{SmX}$} & $137.4(11.4)$ & \multirow{2}{*}{$\mathrm{SmA}$} & $187.1(25.2)$ & $\mathbf{I}$ \\
\hline & $R^{\prime}=\mathrm{C}_{5} \mathrm{H}_{11}$ & & & & $133.0(11.7)$ & & $180.0(27.6)$ & 1 \\
\hline \multirow[t]{2}{*}{$1 \mathrm{c}$} & $R=\mathrm{C}_{6} \mathrm{H}_{13}$ & \multirow{2}{*}{$\mathrm{Cr}$} & 102.1(19.4) & \multirow{2}{*}{$\operatorname{SmX}$} & $149.1(12.1)$ & \multirow{2}{*}{$\mathrm{SmA}$} & $200.7(28.3)$ & $\mathbf{I}$ \\
\hline & & & & & $143.7(10.9)$ & & $193.3(25.4)$ & 1 \\
\hline \multirow[t]{2}{*}{$2 \mathbf{a}$} & $R=\mathrm{C}_{2} \mathrm{H}_{5}$ & \multirow{2}{*}{$\mathrm{Cr}$} & 96.7 (111.8) & \multirow{2}{*}{$\operatorname{SmX}$} & $161.4(8.0)$ & \multirow{2}{*}{$\mathrm{SmA}$} & $209.3(36.2)$ & $\mathrm{I}$ \\
\hline & $R^{\prime}=\mathrm{C}_{9} \mathrm{H}_{19}$ & & & & & & $206.1(37.5)$ & 1 \\
\hline \multirow[t]{2}{*}{$2 \mathbf{b}$} & $R=\mathrm{C}_{4} \mathrm{H}_{9}$ & & & \multirow{2}{*}{$\operatorname{SmX}$} & $150.1(10.5)$ & \multirow{2}{*}{$\mathrm{SmA}$} & $196.4(42.4)$ & I \\
\hline & & & & & $148.6(6.7)$ & & $194.0(38.4)$ & \\
\hline \multirow[t]{2}{*}{$2 c$} & $R=\mathrm{C}_{6} \mathrm{H}_{13}$ & \multirow{2}{*}{$\mathrm{Cr}$} & $104.1(31.7)$ & \multirow{2}{*}{$\operatorname{SmX}$} & $154.1(13.5)$ & \multirow{2}{*}{$\mathrm{SmA}$} & $195.1(30.8)$ & $\mathrm{I}$ \\
\hline & K & & & & $153.1(10.7)$ & & $192.7(28.8)$ & 1 \\
\hline
\end{tabular}

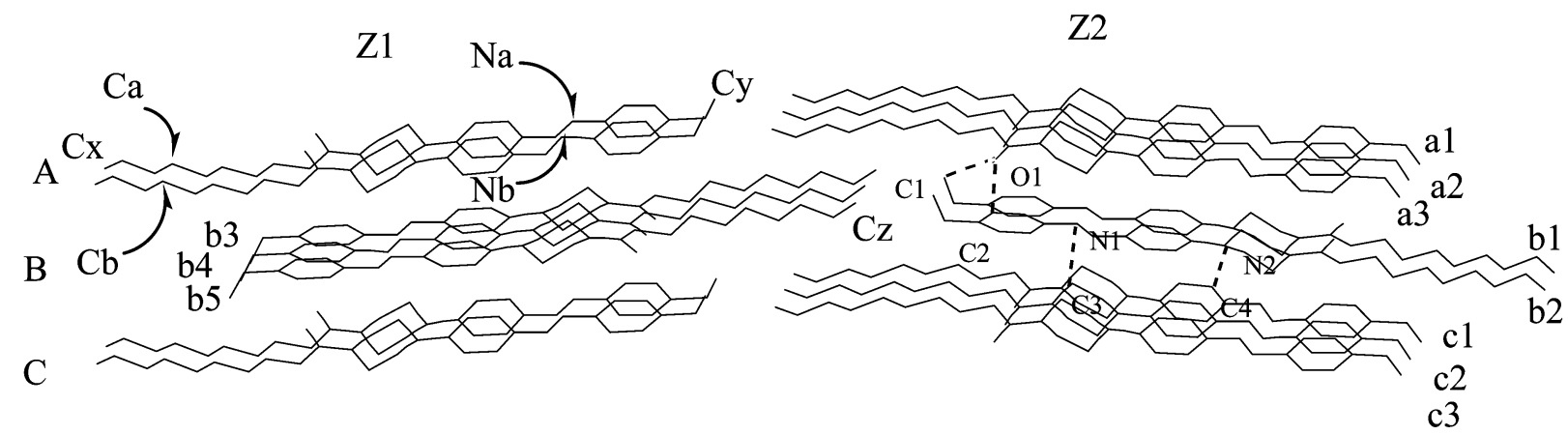

Figure 1. The molecular stacking of azo dye 2a. The hydrogen atoms are omitted for clarity.

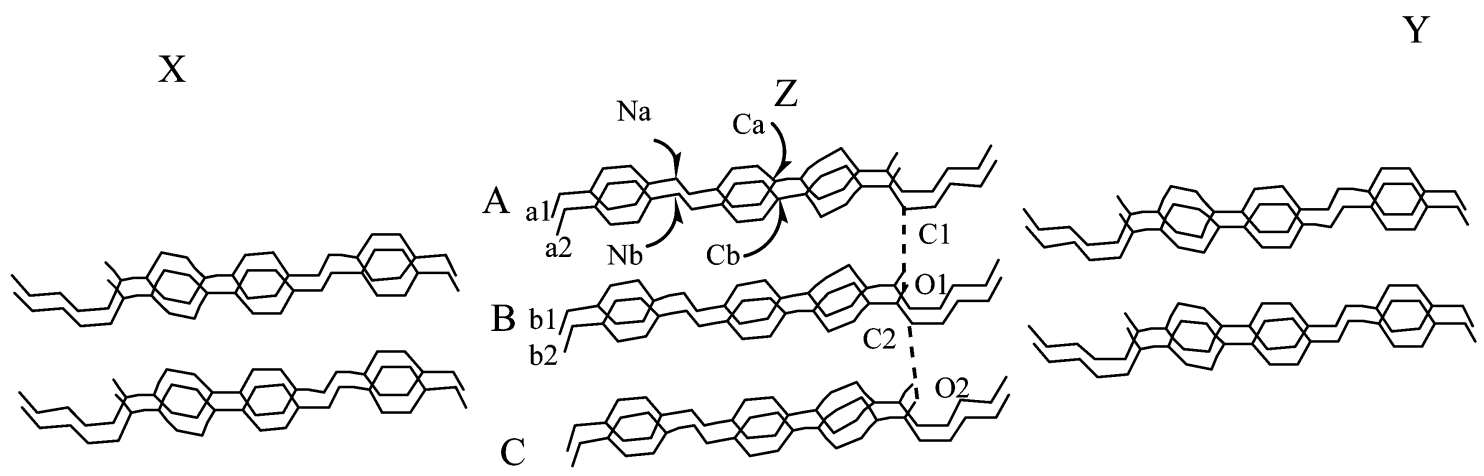

Figure 2. The molecular stacking of azo dye 1a. The hydrogen atoms are omitted for clarity. 
corresponding planes in layer $\mathrm{B}$, and the distances between them are about $3.8 \AA$, half the distance between corresponding atoms in layer A. Similarly, molecules of 2c are regularly arranged head-to-head with adjacent molecules in the A, B or C layer (see figure 3) [5a]. However, molecules in different layers are packed in opposite directions; they are parallel to neighbouring molecules in the same layer and the distances between two corresponding atoms in the same layers (for example, $\mathrm{Na}-\mathrm{Nb}$ and $\mathrm{Ca}-\mathrm{Cb}$ ) are all about $5.72 \AA$. Molecules in different layers are not parallel to each other. The angle between the planes containing diazobenzene moieties of the molecules in layer $\mathrm{A}$ and the corresponding planes in layer $\mathrm{B}$ is about $40^{\circ}$.

It is suggested that the charge distribution of the $\mathrm{N}-\mathrm{C}=\mathrm{O}$ and azobenzene moieties should significantly influence the molecular stacking in the solid state for compounds 1a, 2a and $\mathbf{2 c}$. The charge of molecule 1a, representing this series of compounds, was therefore calculated. The initial structure of $\mathbf{1 a}$ was established on the basis of crystallographic data, and then optimized by the CAChe program using the AM1 model; the charge distribution of the $\mathrm{N}-\mathrm{C}=\mathrm{O}$ and azobenzene moieties in molecule 1a is shown in figure 4. Clearly, in the molecular stacking of 1a (figure 2), the partially negative charge of the $\mathrm{O}$ atom in the $\mathrm{N}-\mathrm{C}=\mathrm{O}$ of one molecule is directed towards the partially positive charge of the $\mathrm{C}$ atom in the $\mathrm{N}-\mathrm{C}=\mathrm{O}$ of another molecule. In the molecular stackings of $\mathbf{2 a}$ and $\mathbf{2 c}$ (figures 1 and 3), the partially positive charge of the $\mathrm{C}$ atom in the $\mathrm{N}-\mathrm{C}=\mathrm{O}$ of one molecule is directed towards the partially negative charge of the azobenzene moiety in another molecule. In addition to the polar functional $\mathrm{N}-\mathrm{C}=\mathrm{O}$ group, the quadrupolar interaction between intermolecular benzene moieties influences the molecular stacking on the solid state [8]. As demonstrated in figures 1 and 3, the aryl-Hs were directed into the planes containing benzene moieties.

The weak intermolecular H-bond interactions appear in the molecular stacking of $\mathbf{2 a}$, as seen in the molecular stackings of $1 \mathbf{a}$ and $\mathbf{2 c}[5 a$ ]. In figure 1 , the H-bond interaction arises both from $\mathrm{O} \ldots \mathrm{H}$ and $\mathrm{N}$...H. The distances $\mathrm{O} 1 \ldots \mathrm{H} 1$ (at $\mathrm{C} 1$ ) and $\mathrm{O} 1 \ldots \mathrm{H} 2$ (at $\mathrm{C} 2$ ) between the $\mathrm{A}-\mathrm{B}$ layers are 3.02 and $2.85 \AA$, respectively; the distances $\mathrm{N} 1 \ldots \mathrm{H} 3$ (at $\mathrm{C} 3$ ) and $\mathrm{N} 2 \ldots \mathrm{H} 4$ (at $\mathrm{C} 4$ ) between the $\mathrm{B}-\mathrm{C}$ layers are 3.01 and $2.87 \AA$, respectively. This intermolecular $\mathrm{H}$-bond interaction is similar to that seen in the molecular stacking of $\mathbf{2 c}$ and slightly different from that of 1a. In 1a (figure 2), the distances of $\mathrm{O} 1 \ldots \mathrm{H} 1$ (at $\mathrm{C} 1$ ) and $\mathrm{O} 1 \ldots \mathrm{H} 2$ (at $\mathrm{C} 2$ ) are both 3.01 A. In 2c (figure 3), the distance $\mathrm{O} 1 \ldots \mathrm{H} 3$ (at $\mathrm{C} 3$ ) between the $\mathrm{A}-\mathrm{B}$ layers is $2.83 \AA$, and the distances $\mathrm{N} 1 \ldots \mathrm{H} 1$ (at $\mathrm{C} 1$ ) and $\mathrm{N} 2 \ldots \mathrm{H} 2$ (at $\mathrm{C} 2$ ) between the $\mathrm{B}-\mathrm{C}$

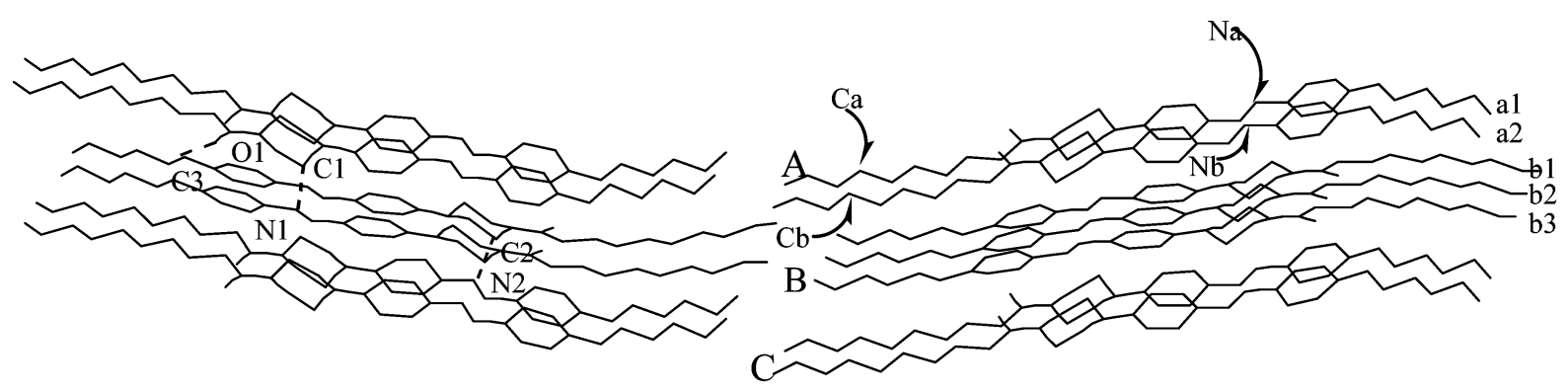

Figure 3. The molecular stacking of azo dye 2c. The hydrogen atoms are omitted for clarity.

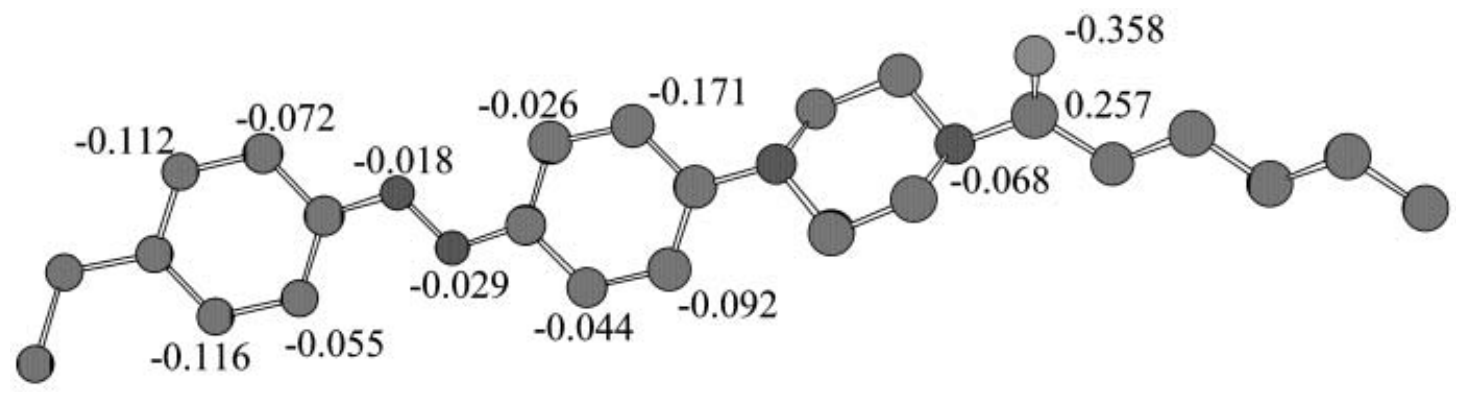

Figure 4. The charge distribution of $\mathrm{N}-\mathrm{C}=\mathrm{O}$ and azobenzene moieties in a molecule of $\mathbf{1 a}$. The hydrogen atoms are omitted for clarity. 
layers are both $2.82 \AA$. All the $\mathrm{O} . . . \mathrm{H}$ distances in figures 1-3 are slightly longer than the sum of the van der Waals radii of $\mathrm{H}$ and $\mathrm{O}$ atoms (Bondi radii: $\mathrm{H}$ $1.20, \mathrm{O} 1.52 \AA)[9 a]$. In an analogous way, all the distances $\mathrm{N}$...H in figures $1-3$ are also slightly longer than the sum of the van der Waals radii of $\mathrm{H}$ and $\mathrm{N}$ atoms (Bondi radii: $\mathrm{H} 1.20, \mathrm{~N} 1.55 \AA$ ) [ $9 a$ ] . These O...H and N...H distances are in the normal hydrogen bond range $[9 b]$.

Based on these observations, it may be concluded that the dipolar interaction between $\mathrm{N}-\mathrm{C}=\mathrm{O}$ groups and the quadrupolar interaction between benzene moieties significantly influence the molecular stackings of compounds 1a, 2a, and 2c. Therefore, all this series of compounds exhibit a SmA phase during thermal processing. However, the weak intermolecular H-bond interaction in the stackings of $\mathbf{2 a}$ and $\mathbf{2 c}$ appears to be stronger than that of 1a. This, together with quadrupolar interaction between benzene moieties, shown in figures 1 and 3, may further explain why the enthalpy difference between the SmA and isotropic phases for azo dyes 1a-1c is slightly lower than corresponding values for azo dyes $\mathbf{2 a - 2 c}$.

As indicated previously, the mesogenic phase of azo dye 2a was characterized as SmA by its typical focalconic texture. However, the molecular stacking of azo dye 2a (figure 1) is less justified than those of azo dyes 1a and 2c (figures 2 and 3). For further characterization, azo dye 2a was then studied by powder XRD. The $d$-spacings ( $Z$ component of an extended molecular length) from XRD at 200,180 and $160^{\circ} \mathrm{C}$ were all measured to be $30.59 \AA$ during cooling. As the molecular axis of liquid crystals in the SmA phase is directed along the $Z$ axis, the $d$-spacing of the molecule may not vary with temperature in this range. As the molecular arrangement between the columns in figure 1 is less justified, the identification of the $d$-spacing is thus less straightforward. Calculation of the length of the extended molecule 2a was therefore undertaken. To obtain a realistic result, the starting conformation of molecule 2a was first established on the basis of crystallographic data and then optimized by the CaChe program (version 4.1) using the AM1 model. After optimization, the length of the extended molecule 2a was calculated to be $26.90 \AA$ (from $\mathrm{Cx}$ to $\mathrm{Cy}$ in figure 1), which is shorter than the $d$-spacing obtained by XRD. However, the distance between $\mathrm{Cx}$ and $\mathrm{Cz}$ is $32.84 \AA$, which is longer than the $d$-spacing. Therefore, it is suggested that the molecules b3-b5 shift relatively to the left at elevated temperature, leading to a more justified arrangement between the columns. Thus the $d$ spacing $(30.59 \AA)$ obtained by XRD is in the range of 26.90-32.84 A.

\section{Conclusion}

We have shown that azo dyes 1a, $\mathbf{2 a}$ and $\mathbf{2 c}$, containing the same mesogenic rigid core, exhibit significantly different molecular stackings owing to the different lengths of alkyl chains. These dyes also show various types of H-bond interaction among the molecular layers. Although variation of the alkyl chain length does not result in a different liquid crystalline phase in this system, such variation does cause different enthalpy changes during thermal processing. The introduction of other effects, together with the variation of alkyl chain length, may result in the variation of liquid crystalline phases as demonstrated in azo dyes $\mathbf{3 a}$ and $\mathbf{3 b}$, which is very important theoretically and in LCD applications. Different azo dye systems with other functional groups will therefore be synthesized and their physical properties studied systematically in future studies.

\section{Acknowledgements}

We thank the National Chi Nan University and the National Science Council (NSC 92-2113-M-260-004) for financial support. The National Center of HighPerforming Computing and the Institute of Chemistry, Academia Sinica are also highly appreciated for providing the Beilstein database system, and a most helpful library service, respectively.

\section{References}

[1] (a) J.-M. Lehn. Supramolecular Chemistry. VCH, Weinheim (1995); (b) A.D. Hamilton. Perspectives in Supramolecular Chemistry (John Wiley) (1996).

[2] (a) C.A. Hunter. Angew. Chem. int. Ed. Engl., 32, 1584 (1993); (b) C.A. Hunter. Chem. Soc. Rev., 23, 101 (1994).

[3] (a) G.R. Desiraju. Crystal Engineering: The Design of Organic Solids. Elsevier, New York (1989); (b) G.R. Desiraju. Chem. Commun., 1475 (1997).

[4] (a) K.M. Lee, C.M. Lee and I.J.B. Lin. Angew. Chem. int. Ed. Engl., 36, 1850 (1997); (b) J. Chang and J.S. Moore. J. Am. chem. Soc., 116, 2655 (1994).

[5] (a) L.L. Lai, E. Wang, Y.H. Liu and Y. Wang. Liq. Cryst., 29, 871 (2002); (b) L.L. Lai, F.-Y. Su and C.-H. Hung. Liq. Cryst., 31, 773 (2004).

[6] (a) L.L. Lai, L.J. Lee, G.H. Lee, Y. Wang, K.L. Lu and S.J. Lee. Liq. Cryst., 28, 1513 (2001); (b) H. McNab and L.C. Monahan. J. chem. Soc. Perkin Trans. 1, 419 (1989).

[7] G.M. Sheldrick. SHELXTL version 5.03. Siemens Analytical X-ray Instruments Inc., Madison, Wisconsin (1994).

[8] (a) W. Haase and M.A. Athanassopoulou. Struct. Bonding, 44, 140 (1999) and references therein; (b) Z. Ciunik and G.R. Desiraju. Chem. Commun., 703 (2001).

[9] (a) A. Bondi. J. phys. Chem., 68, 441 (1964); (b) F.H. Allen, J.M.P. Lommerse, V.J. Hoy, J.A.K. Howard and G.R. Desiraju. Acta Cryst., B52, 734 (1996). 
Copyright of Liquid Crystals is the property of Taylor \& Francis Ltd and its content may not be copied or emailed to multiple sites or posted to a listserv without the copyright holder's express written permission. However, users may print, download, or email articles for individual use. 